\title{
MENINGKATKAN MINAT DAN KEMAMPUAN SISWA DALAM MENULIS KARANGAN MELALUI MEDIA GAMBAR PADA SISWA KELAS IV MI NO. 25/E.3 AMBAI BAWAH KAB. KERINCI TAHUN AJARAN 2017/2018
}

\author{
Citra Dewi \\ Guru MI No. 25/E.3 Ambai Bawah Kerinci \\ Email: citrad643@gmail.com
}

\begin{abstract}
Abstrak
Salah satu peran guru yang sangat penting adalah menciptakan proses pembelajaran yang bermutu, berkualitas dan menyenangkan. Adapun tujuan dari penelitian tindakan kelas ini untuk mengetahui seberapa besar dampak peningkatan minat siswa terhadap penggunaan media gambar yang diinterprestasikan menjadi sebuah karangan Meningkatkan kemampuan minat siswa dapat dilihat dari beberapa aspek yaitu : aktivitas siswa, aktivitas guru dan efektivitas proses pembelajaran, dan nilai hasil prestasi siswa.

Teknik yang digunakan adalah dengan pendekatan penelitian tindakan kelas, teknik pengumpulan data observasi, dan tes hasil belajar siswa. Perolehan data baik aktivitas siswa maupun nilai hasil belajar sisiwa pada siklus I dan II dalam penelitian tindakan kelas dapat ditafsirkan sebagai berikut ; (1) Minat dan kemampuan siswa terhadap pembelajaran menulis karangan sangat baik. (2) Media Gambar sangat membantu siswa dalam meningkatkan imajinasi sehingga mampu membuat kalimat sederhana yang menjadi kerangka karangan dan kemudian dikembangkan lagi. (3) Siswa mampu menginterprestasikan kalimat sederhana dengan cara mengkaitkan gambar seri yang diamatinya. (4) Siswa mampu mengkomunikasikan tulisannya berdasarkan hasil pengamatan kepada temannya maupun kepada guru. (5) Proses pembelajaran lebih variatif sehingga anak menjadi kreatif, aktif dan menyenangkan. (6) Pembelajaran lebih efektif, karena terfokus pada media gambar. (7) Pembelajaran akan kondusif, karena perhatian siswa tertuju pada media gambar yang telah disediakan. (8) Guru mudah untuk mengevaluasi hasil kegiatan anak terutama pada aspek minat dan kemampuan siswa. (9) Dapat dijadikan tolak ukur pada pembelajaran berikutnya.
\end{abstract}

Kata Kunci : Kemampuan, Minat dan Media Gambar 


\section{A. PENDAHULUAN}

\section{Latar Belakang Masalah}

Proses pembelajaran yang bermutu dan berkualitas tergantung pada guru yang mampu dan dapat mengaktifkan siswanya dalam proses belajar Dimana siswa diberi kesempatan untuk mencoba, mengalami dan dapat melaksanakan atau mempraktekkan apa yang telah dipelajarinya untuk memperoleh hasil yang lebih baik. H.G. Tarigan mengemukakan bahwa keterampilan berbahasa memiliki empat komponen, yaitu : keterampilan menyimak, keterampilan berbicara, keterampilan membaca dan keterampilan menulis (H.G. Tarigan : 1968 :1) Keempat keterampilan berbahasa di atas merupakan suatu kesatuan yang tidak dapat dipisahkan, tetapi hanya dapat dibedakan. Keterampilan yang satu bergantung kepada ketiga keterampilan yang lainnya. Contohnya seseorang trampil menulis karena mampu membaca ,menyimak dan berbicara. Untuk itu dapat disimpulkan bahwa pengajaran Bahasa Indonesia dalam aspek menulis merupakan salah satu komponen yang dapat menentukan dan mencapai tujuan pembelajaran yang diharapkan.

Kenyataan di lapangan sebagian besar siswa masih kurang memiliki kemampuan dalam menuangkan ide-ide atau gagasan yang dapat dituliskan pada sebuah karangan. Salah satu alternative untuk memecahkan masalah siswa tersebut adalah dilakukan kegiatan menulis karangan dengan mempergunakan media gambar. Melalui kegiatan ini siswa dilatih untuk mengekpresikan perasaan dan pikirannya sehingga dapat mengungkapkan ide-ide dan gagasan dalam bentuk menulis karangan. Disamping itu siswa dilatih menulis karangan dengan ejaan yang benar sesuai dengan tema gambar. Secara bertahap siswa dapat berekspresi mulai dari penetapan paragraph pada gambar seri yang tepat, kemudian dapat mengembangkan pokok pikiran melalui membuat kalimat sederhana sampai pada peulisan karangan yang diharapkan.

Dari hasil prestasi rata-rata siswa dari sejumlah 33 siswa pada mata pelajaran Bahasa Indonesia di semester satu tahun pelajaran 2016-2017 mencapai 64,50 sedangkan Kriteria Ketuntasam Minimal sebesar 66,50, dengan kata lain belum mencapai target yang diharapkan. 
Berdasarkan hasil pengamatan tersebut, untuk mengatasi kesulitan siswa dalam menulis karangan, penulis mengadakan perbaikan pembelajaran pada mata pelajaran Bahasa Indonesia dengan Penelitian Tindakan Kelas dengan judul "Meningkatkan Minat Dan Kemampuan Siswa Dalam Menulis Karangan Melalui Media Gambar Pada Siswa Kelas IV MI No. 25/E.3 Ambai Bawah Kabupaten Kerinci”

\section{Rumusan Masalah Penelitian.}

a. Apakah media gambar dapat meningkatkan minat dan kemampuan siswa dalam menulis karangan ?

b. Bagaimana proses kemampuan minat siswa dalam menulis karangan sebelum dan sesudah menggunakan media gambar?

c. Seberapa besar penggunaan media gambar dapat meningkatkan kemampuan minat siswa dalam menulis karangan?

\section{Tujuan Penelitian}

a. Meningkatkan minat siswa dalam menulis karangan melalui media gambar.

b. Menganalisis apakah media gambar dapat diterima siswa sebagai kemudahan dalam menulis karangan.

c. Mengukur seberapa besar penggunaan media gambar dapat meningkatkan kemampuan siswa dalam menulis karangan.

\section{Manfaat Penelitian}

a. Bagi Siswa :

- Meningkatkan motivasi siswa dalam belajar menulis karangan dengan menggunakan media gambar.

- Mengembangkan kemampuan berfikir kreatif, kritis dan komunikatif dalam menulis sesuai dengan ejaan yang benar.

- Siswa aktif dalam proses pembelajaran Bahasa Indonesia. 


\section{b. Bagi Guru :}

- Mengetahui media yang sesuai dalam proses belajar mengajar dan dapat mengembangkan penggunaan media gambar secara variatif.

- Meningkatkan kwalitas pembelajaran bahasa Indonesia khususnya dalam menulis karangan.

\section{B. KAJIAN TEORI}

\section{Media Gambar}

Media berasal dari bahasa latin "Medium" yang secara harfiah berarti "Perantara"atau "Pengantar" yaitu perantara atau pengantar sumber pesan dengan penerima pesan. Schramm (1977) mengemukakan bahwa media pembelajaran adalah teknologi pembawa pesan yang dapat dimanfaatkan untuk keperluan pembelajaran. Sementara Briggs (1977) berpendapat bahwa media pembelajaran adalah sarana fisik untuk menyampaikan isi/materi pembelajaran seperti : buku, film, video dsb.

Gambar adalah segala sesuatu yang diwujudkan secara visual kedalam bentuk dua dimensi sebagai hasil perasaan dan pikiran. Teori Piaget (Mohamad Surya : 2004) usia anak 6 - 12 tahun perkembangan kecerdasannya pada peringkat operasional konkrit (concrete operational) anak telah dapat membuat pemikiran tentang situasi atau hal konkrit secara logis menyatakan bahwa anak usia sekolah dasar berada pada tahap operasional konkrit, ini menunjukkan bahwa anak sangat menyukai benda yang nyata, disamping itu anak memiliki daya fantasi yang sangat tinggi.

Dengan media gambar anak dapat terbantu menuangkan gagasan serta ide kedalam bentuk bahasa karena gambar akan member inspirasi dan panduan tentang apa dan bagaimana yang harus ditulis. Gambar juga dapat menimbulkan daya tarik tersendiri sehingga dapat mempermudah dan memperjelas bagian terpenting dari rangkaian gambar seri yang ada.

Menurut (Hidayat, dan Rahmina : 2003) mengemukakan fungsi dari media gambar adalah : 
a. Sebagai alat bantu untuk menciptakan situasi belajar yang efektif.

b. Sebagai bagian integral dalam keseluruhan situasi belajar sehingga dapat meningkatkan hasil belajar.

c. Sebagai pelengkap suatu proses pembelajaran untuk menarik perhatian siswa.

d. Untuk memperlancar proses pembelajaran sehingga siswa mudah paham dalam menerima materi.

e. Untuk meningkatkan hasil belajar dan mutu belajar.

Sedangkan keuntungan dari media gambar diantaranya adalah :

a. Dapat menerjemahkan ide/gagasan yang sifatnya abstrak menjadi lebih realistic.

b. Banyak tersedia dalam buku-buku (termasuk buku teks), majalah, surat kabar, kelender, dsb.

c. Mudah menggunakannya dan tidak memerlukan peraturan lain.

d. Tidak mahal bahkan mungkin tanpa mengeluarkan biaya untuk pengadaannya.

e. Dapat digunakan pada setiap tahap pembelajaran dan semua mata pelajaran/disiplin ilmu.

\section{Menulis Karangan}

Menurut Sa'adah (2003) menulis berarti mengekpresikan secara tertulis gagasan, ide, pendapat, pikiran atau perasaan melalui bahasa. Batasan menulis yang dikemukakan oleh Nurjiyantoro ( 1995 ) adalah menulis sebagai aktivitas produktif dan aktivitas pengungkapan bahasa. Secara umum bahwa menulis adalah aktivitas mengungkapkan gagasan melalui media bahasa.

Para ahli berpendapat bahwa factor yang mendorong kemampuan menulis adalah :

a. Kemampuan mendapatkan tema karangan yang akan dikembangkan menjadi isi karangan.

b. Kemampuan mengembangkan tema menjadi kerangka atau sistematik isi karangan.

c. Kemampuan mengembangkan kerangka menjadi suatu karangan yang lengkap.

d. Kemampuan bidang ketatabahasaan. 
e. Kemampuan bidang gaya bahasa yang meliputi diksi, memilih kalimat efektif,sugestif dan menarik.

f. Kemampuan dalam bidang arti kata.

g. Kemampuan dalam bidang kosakata

h. Kemampuan dalam bidang ejaan dan pungtuasif.

Menulis karangan merupakan salah satu keterampilan berbahasa dalam aspek menulis. Karangan dalam bentuk tulisan sehingga pesan yang disampaikan dalam tulisan tersebut dapat dipahami oleh pembaca. Menulis karangan dengan ejaan yang benar merupakan keterampilan berbahasa yang masih dianggap sulit bagi siswa kelas III MI. Ada beberapa langkah untuk memotivasi minat dan kemampuan siswa yaitu dengan media gambar seri. Sehingga siswa akan akan terangsang untuk menemukan tema atau topik karangan tersebut. Sebagaimana diungkapkan oleh ( Juanda : 1996) Langkah-langkah yang dilakukan oleh siswa agar tidak menemui kesulitan dalam mengarang cerita, antara lain : 1) mencari topik, 2) menentukan tujuan, 3) kepada siapa karangan itu ditujukan, dan 4) mewujudkan karangan diatas kertas.

Agar siswa terampil dalam menulis karangan perlu dibekali teknik-teknik dalam mengarang. Menurut Maecus (1984) ada beberapa teknik mengarang diantaranya :

a. Memilih tema.

b. Menngembangkan tokoh dan wataknya.

c. Plot atau kerangka karangan.

d. Sudut pandang (point of view)

e. Jumlah halaman dan pembagian bab

f. Memilih judul

g. Permulaan yang baik dalam menulis karangan.

\section{METODOLOGI PENELITIAN}

\section{Metode Penelitian}

Metode yang digunakan dalam Penelitian Tindakan Kelas ini adalah Deskriptif Analitik, yaitu studi yang digunakan untuk mengumpulkan data, 
mendeskripsikan, mengolah, menganalisa, menyimpulkan dan menafsirkan data sehingga memperoleh gambaran yang sistematis.

\section{Subjek dan Lokasi Penelitian}

Penelitian tindakan kelas ini dilaksanakan di MI No. 43/E.3 Tamiai Kabupaten Kerinci. Subjek penelitian ini adalah kelas III dengan jumlah siswa sebanyak 30 orang. Kelas tersebut dipakai sebagai subjek penelitian karena ratarata hasil uji kompetensi siswa yang mencapai KKM hanya 43,33\% dan hasil belajarnya masih belum memuaskan. Oleh karena itu memerlukan penanganan yang segera.

\section{Instrumen Penelitian}

Untuk memperoleh data yang diperlukan oleh penulis, digunakan instrumen pengumpulan data sebagai berikut:

a. Tes Uji Kompetensi

b. Lembar Observasi

\section{Prosedur Penelitian}

Penelitian Tindakan Kelas (PTK) ini dilaksanakan dengan empat tahapan sesuai dengan model John Elliot (Muslihuddin, 2010:72) yang dimulai dari perencanaan, pelaksanaan, pengamatan dan refleksi.

\section{Analisis Data}

Analisis data yang digunakan dalam penelitian ini yaitu teknik kuantitatif yang berupa perhitungan dan teknik kualitatif yang berupa uraian. Setelah data terkumpul dan diperiksa, apabila memenuhi persyaratan maka data tersebut ditabulasikan dalam tabel yang telah siap untuk pengolahan. Setelah itu dicek kebenarannya kemudian dihitung persentasenya. 


\section{HASIL PENELITIAN DAN PEMBAHASAN}

\section{Hasil Penelitian}

\section{- Kegiatan Pendahuluan}

Pada bab ini akan menyajikan hasil analisis data yang telah diperoleh Sebelum melakukan tindakan dalam penelitian, peneliti melakukan observasi awal di kelas tentang prestasi pelajaran bahasa Indonesia dalam menulis karangan. Hasil observasi menunjukkan bahwa hasil belajar siswa pada mata pelajaran bahasa Indonesia terutama dalam menulis karangan masih tergolong rendah dan guru masih belum optimal memanfaatkan media pembelajaran. Berdasarkan hal tersebut, maka diputuskanlah untuk menggunakan media gambar dalam materi menulis karangan pada siswa kelas IV MI No. 25/E.3 Ambai Bawah Kabupaten Kerinci.

Pembelajaran dimulai dengan mengadakan tugas awal di kelas III untuk mengetahui kemampuan awal siswa dalam menulis karangan. Nilai tugas awal dijadikan acuan untuk mengetahui hasil kemampuan siswa kelas III setelah menggunakan media gambar. Tugas awal tentang menulis karangan sederhana. Perolehan nilai tugas awal ini akan dijadikan acuan untuk mengetahui peningkatan hasil kemampuan siswa setelah menggunakan media gambar. Berikut disajikan data hasil belajar siswa pada prasiklus.

Tabel 1

Data Hasil Belajar Siswa Pada Prasiklus

\begin{tabular}{|c|c|c|l|}
\hline No & $\begin{array}{c}\text { Nama Siswa } \\
\text { (Inisial) }\end{array}$ & Nilai & Ketuntasan \\
\hline 1 & A & 55 & $\begin{array}{l}\text { Belum } \\
\text { Tuntas }\end{array}$ \\
\hline 2 & B & 50 & \begin{tabular}{l} 
Tuntas \\
\hline 3
\end{tabular} \\
\hline 4 & C & 70 & Tuntas \\
\hline 5 & D & 65 & Tuntas \\
\hline
\end{tabular}




\begin{tabular}{|c|c|c|c|}
\hline & & & Tuntas \\
\hline 6 & $\mathrm{~F}$ & 50 & $\begin{array}{l}\text { Belum } \\
\text { Tuntas }\end{array}$ \\
\hline 7 & $\mathrm{G}$ & 60 & $\begin{array}{l}\text { Belum } \\
\text { Tuntas }\end{array}$ \\
\hline 8 & $\mathrm{H}$ & 60 & $\begin{array}{l}\text { Belum } \\
\text { Tuntas }\end{array}$ \\
\hline 9 & I & 65 & Tuntas \\
\hline 10 & $\mathrm{~J}$ & 70 & Tuntas \\
\hline 11 & $\mathrm{~K}$ & 50 & $\begin{array}{l}\text { Belum } \\
\text { Tuntas }\end{array}$ \\
\hline 12 & $\mathrm{~L}$ & 75 & Tuntas \\
\hline 13 & $\mathrm{M}$ & 55 & $\begin{array}{l}\text { Belum } \\
\text { Tuntas }\end{array}$ \\
\hline 14 & $\mathrm{~N}$ & 55 & $\begin{array}{l}\text { Belum } \\
\text { Tuntas }\end{array}$ \\
\hline 15 & $\mathrm{O}$ & 55 & $\begin{array}{l}\text { Belum } \\
\text { Tuntas }\end{array}$ \\
\hline 16 & $\mathrm{P}$ & 50 & $\begin{array}{l}\text { Belum } \\
\text { Tuntas }\end{array}$ \\
\hline 17 & $\mathrm{Q}$ & 60 & $\begin{array}{l}\text { Belum } \\
\text { Tuntas }\end{array}$ \\
\hline 18 & $\mathrm{R}$ & 60 & $\begin{array}{l}\text { Belum } \\
\text { Tuntas }\end{array}$ \\
\hline 19 & $S$ & 55 & $\begin{array}{l}\text { Belum } \\
\text { Tuntas }\end{array}$ \\
\hline 20 & $\mathrm{~T}$ & 60 & $\begin{array}{l}\text { Belum } \\
\text { Tuntas }\end{array}$ \\
\hline 21 & $\mathrm{U}$ & 70 & Tuntas \\
\hline 22 & $\mathrm{~V}$ & 60 & Belum \\
\hline
\end{tabular}




\begin{tabular}{|c|c|c|c|}
\hline & & & Tuntas \\
\hline 23 & W & 60 & $\begin{array}{l}\text { Belum } \\
\text { Tuntas }\end{array}$ \\
\hline 24 & $\mathrm{X}$ & 70 & Tuntas \\
\hline 25 & $\mathrm{Y}$ & 50 & $\begin{array}{l}\text { Belum } \\
\text { Tuntas }\end{array}$ \\
\hline 26 & $\mathrm{Z}$ & 70 & Tuntas \\
\hline 27 & A. 1 & 50 & $\begin{array}{l}\text { Belum } \\
\text { Tuntas }\end{array}$ \\
\hline 28 & A. 2 & 55 & $\begin{array}{l}\text { Belum } \\
\text { Tuntas }\end{array}$ \\
\hline 29 & A. 3 & 55 & $\begin{array}{l}\text { Belum } \\
\text { Tuntas }\end{array}$ \\
\hline 30 & A. 4 & 50 & $\begin{array}{l}\text { Belum } \\
\text { Tuntas }\end{array}$ \\
\hline & Rata-Rata & 59,00 & \\
\hline & Nilai Tertinggi & 70 & \\
\hline & Nilai Terendah & 50 & \\
\hline & $\begin{array}{l}\text { Persentase } \\
\text { Ketuntasan }\end{array}$ & 26,66 & \\
\hline
\end{tabular}

Jika digambarkan dalam bentuk grafik, maka data hasil kemampuan siswa pada prasiklus tersaji pada grafik 4.1 berikut. 

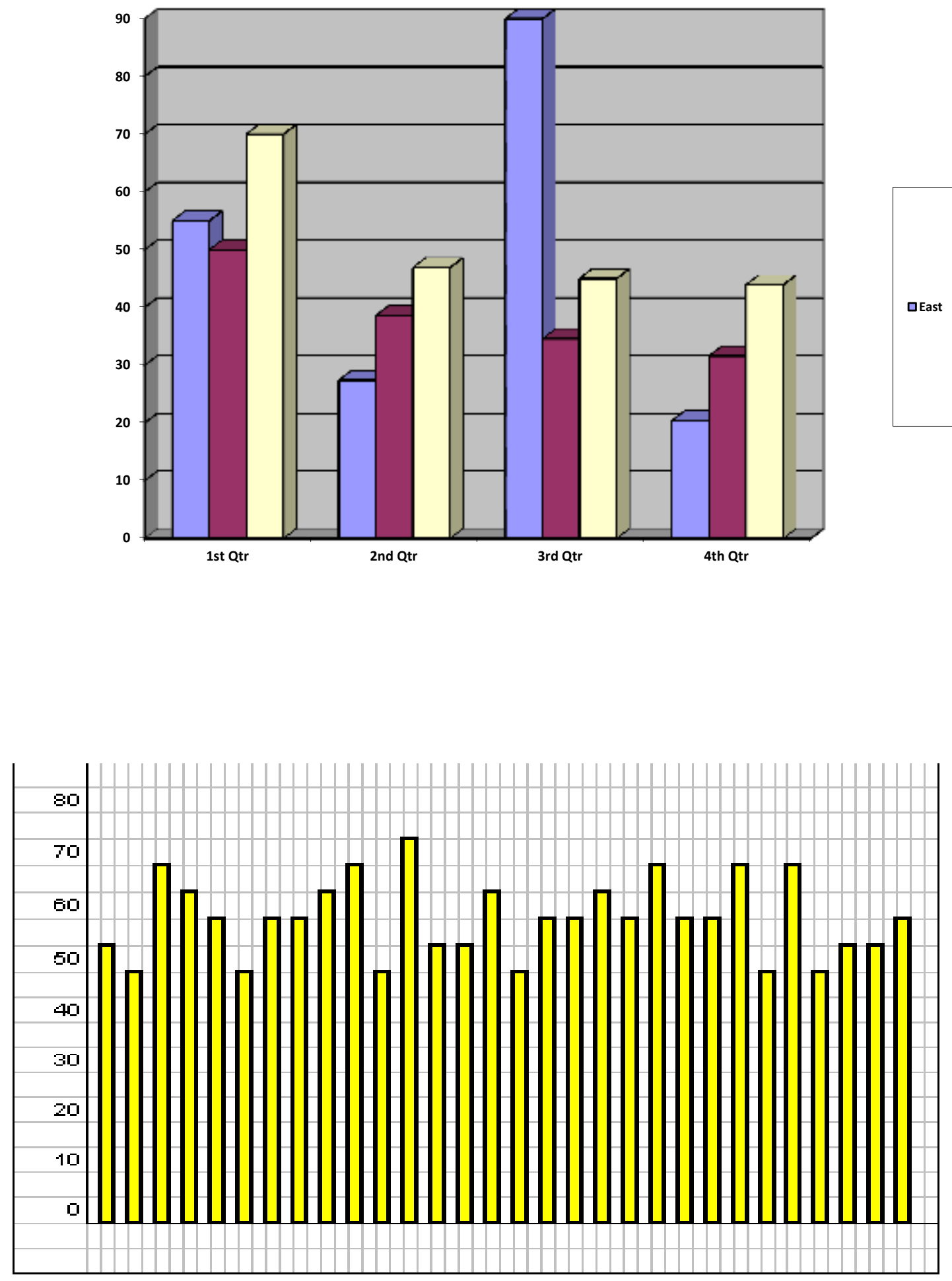

Grafik 4.1

Data Hasil Kemampuan Siswa Pada Prasiklus 
Berdasarkan tabel dan grafik 4.1 terlihat bahwa siswa hanya memperoleh rata-rata 59 dengan nilai tertinggi 70 dan nilai terendah 50. Siswa yang hasil belajarnya diatas KKM hanya 8 orang atau hanya 26,66\% dari nilai KKM yang ditetapkan yaitu 65. Hal ini memberikan gambaran bahwa hasil kemampuan siswa pada mata pelajaran bahasa Indonesia tentang menulis karangan masih tergolong rendah.

\section{Tindakan Siklus I}

a. Perencanaan Tindakan

1) Sebelum menyusun rencana pembelajaran, peneliti melakukan identifikasi masalah dan merencanakan langkah-langkah yang akan dilaksanakan pada siklus I.

2) Setelah peneliti mengetahui masalah dan langkah-langkah yang akan digunakan pada tindakan di siklus I, peneliti kemudian membuat Rencana Pelaksanaan Pembelajaran (RPP).

3) Menentukan pokok bahasan yang akan dijadikan materi bahasan pada penelitian.

4) Mengembangkan Rencana Pelaksanaan Pembelajaran (RPP).

5) Menyiapkan alat peraga media gambar.

6) Mengembangkan format evaluasi.

7) Mengembangkan format observasi pembelajaran.

b. Pelaksanaan Tindakan

Pelaksanaan tindakan pada siklus I dilaksanakan dalam dua kali pertemuan yaitu sebagai berikut.

1) Pelaksanaan pembelajaran pada pertemuan pertama

Hari / Tanggal : Selasa, 4 Agustus 2016

a Guru terlebih dahulu meneliti tingkat kesiapan siswa, mengecek absensi siswa serta mengondisikan kelas agar pembelajaran dapat berlangsung secara kondusif.

b Melakukan apersepsi dengan tanya jawab tentang materi yang akan disampaikan.

c. Selanjutnya guru menjelaskan materi secara singkat tentang menulis karangan.. 
d Guru menjelaskan cara menulis karangan dengan menggunakan media gambar

e Siswa mengerjakan tugas menulis karangan sederhana dengan memperhatikan media gambar yang di tempel di papan tulis.

f Guru menutup pelajaran dengan membimbing siswa dengan tanya jawab secara klasikal untuk menarik kesimpulan tentang menulis karangan yang baik dan benar. Dalam kesempatan ini siswa diberi kesempatan untuk menanyakan hal yang belum jelas dari materi yang telah disampaikan.

2) Pelaksanaan pembelajaran pada pertemuan kedua

Hari / Tanggal : 11 Agustus 2016

a Guru terlebih dahulu meneliti tingkat kesiapan siswa, mengecek absensi siswa serta mengondisikan kelas agar pembelajaran dapat berlangsung secara kondusif.

b Melakukan apersepsi dengan tanya jawab tentang materi yang akan disampaikan.

c. Selanjutnya guru menjelaskan materi secara singkat tentang cara menulis karangan.

d. Guru menjelaskan materi dengan menggunakan media gambar

e. Siswa menyelesaikan tugas tentang menulis karangan.

f. Guru menutup pelajaran dengan membimbing siswa dengan tanya jawab secara klasikal untuk menarik kesimpulan tentang menulis karangan yang baik dan benar. Dalam kesempatan ini siswa diberi kesempatan untuk menanyakan hal yang belum jelas dari materi yang telah disampaikan.

c. Observasi

Dari hasil observasi siklus I, diperoleh kesimpulan bahwa dalam melaksanakan pembelajaran bahasa Indonesia tentang menulis karangan dengan menggunakan media gambar pada siklus I, guru dapat menerapkannya sesuai dengan Rencana Pelaksanaan Pembelajaran (RPP) yang telah disiapkan.

Berdasarkan hasil pengamatan yang dilakukan oleh observer, guru di dalam menyampaikan cara menulis karangan kurang jelas dan mengenai penulisan ejaannya tidak dijelaskan, sehingga masih ada siswa yang kurang paham dalam penulisan ejaannya. Selain itu masih ada siswa yang kurang memperhatikan. 
Data mengenai keaktifan siswa dapat diperoleh dengan menggunakan lembar observasi seperti pada lampiran. Keaktifan siswa tersebut dapat dilihat dalam hal bertanya, berdiskusi dengan teman maupun membenarkan kesalahan teman pada saat proses pembelajaran berlangsung. Data mengenai keaktifan siswa pada siklus I dapat dilihat pada tabel 4.2

Tabel 4.2

Data Mengenai Keaktifan Siswa Pada Siklus I

\begin{tabular}{|c|c|c|c|c|}
\hline \multirow{2}{*}{ No } & \multirow{2}{*}{ Nama } & \multicolumn{3}{|c|}{ 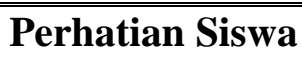 } \\
\hline & & B & $\mathrm{C}$ & $\mathbf{K}$ \\
\hline 1 & $\mathrm{~A}$ & & $\mathrm{~V}$ & \\
\hline 2 & B & & & $\mathrm{V}$ \\
\hline 3 & $\mathrm{C}$ & $\mathrm{V}$ & & \\
\hline 4 & $\mathrm{D}$ & & $\mathrm{V}$ & \\
\hline 5 & $\mathrm{E}$ & & $\mathrm{V}$ & \\
\hline 6 & $\mathrm{~F}$ & & & $\mathrm{~V}$ \\
\hline 7 & G & & $\mathrm{v}$ & \\
\hline 8 & $\mathrm{H}$ & $\mathrm{V}$ & & \\
\hline 9 & I & $\mathrm{V}$ & & \\
\hline 10 & $\mathrm{~J}$ & $\mathrm{~V}$ & & \\
\hline 11 & $\mathrm{~K}$ & & $\mathrm{~V}$ & \\
\hline 12 & $\mathrm{~L}$ & $\mathrm{~V}$ & & \\
\hline 13 & $\mathrm{M}$ & & $\mathrm{v}$ & \\
\hline 14 & $\mathrm{~N}$ & & $\mathrm{~V}$ & \\
\hline 15 & $\mathrm{O}$ & & $\mathrm{v}$ & \\
\hline 16 & $\mathrm{P}$ & & $\mathrm{v}$ & \\
\hline 17 & Q & $\mathrm{v}$ & & \\
\hline 18 & $\mathrm{R}$ & & $\mathrm{v}$ & \\
\hline 19 & $S$ & & $\sqrt{ }$ & \\
\hline 20 & $\mathrm{~T}$ & & $\sqrt{ }$ & \\
\hline
\end{tabular}




\begin{tabular}{||c|c|c|c|c|}
\hline 21 & $\mathrm{U}$ & $\mathrm{v}$ & & \\
\hline 22 & $\mathrm{~V}$ & $\mathrm{v}$ & & \\
\hline 23 & $\mathrm{~W}$ & $\mathrm{v}$ & & \\
\hline 24 & $\mathrm{X}$ & $\mathrm{v}$ & & \\
\hline 25 & $\mathrm{Y}$ & & & $\mathrm{v}$ \\
\hline 26 & $\mathrm{Z}$ & $\mathrm{v}$ & & \\
\hline 27 & A.1 & & & $\mathrm{v}$ \\
\hline 28 & A.2 & & & $\mathrm{v}$ \\
\hline 29 & A.3 & & $\mathrm{v}$ & \\
\hline 30 & A.4 & & $\mathrm{v}$ & \\
\hline
\end{tabular}

Hasil data mengenai aktifitas siswa pada siklus I menunjukkan bahwa sebagian besar siswa termotivasi dalam mengikuti kegiatan pembelajaran. Selanjutnya di bawah ini hasil pengamatan observer tentang aktivitas guru pada siklus I dapat dilihat pada tabel 4.3.

Tabel 4.3

Data Hasil Pengamatan Aktivitas Guru Pada Siklus I

\begin{tabular}{|c|c|c|c|c|}
\hline \multirow[t]{2}{*}{ No } & \multirow[t]{2}{*}{ Aspek Yang Diamati } & \multicolumn{3}{|c|}{ Penilaian } \\
\hline & & Baik & Cukup & Kurang \\
\hline \multirow{3}{*}{1} & Pendahuluan & & & \\
\hline & a. Memotivasi siswa & $\mathbf{V}$ & & \\
\hline & b. Apersepsi & & $\mathbf{v}$ & \\
\hline \multirow{4}{*}{2} & Kegiatan Inti & & & \\
\hline & $\begin{array}{l}\text { - Bahan bahan pembelajaran yang } \\
\text { disajikan sesuai dengan yang } \\
\text { direncanakan }\end{array}$ & V & & \\
\hline & $\begin{array}{l}\text { - Kesesuaian alat peraga dengan } \\
\text { materi }\end{array}$ & $\mathrm{V}$ & & \\
\hline & $\begin{array}{l}\text { - Kemampuan mengoptimalkan } \\
\text { alat peraga }\end{array}$ & & $\mathrm{V}$ & \\
\hline
\end{tabular}




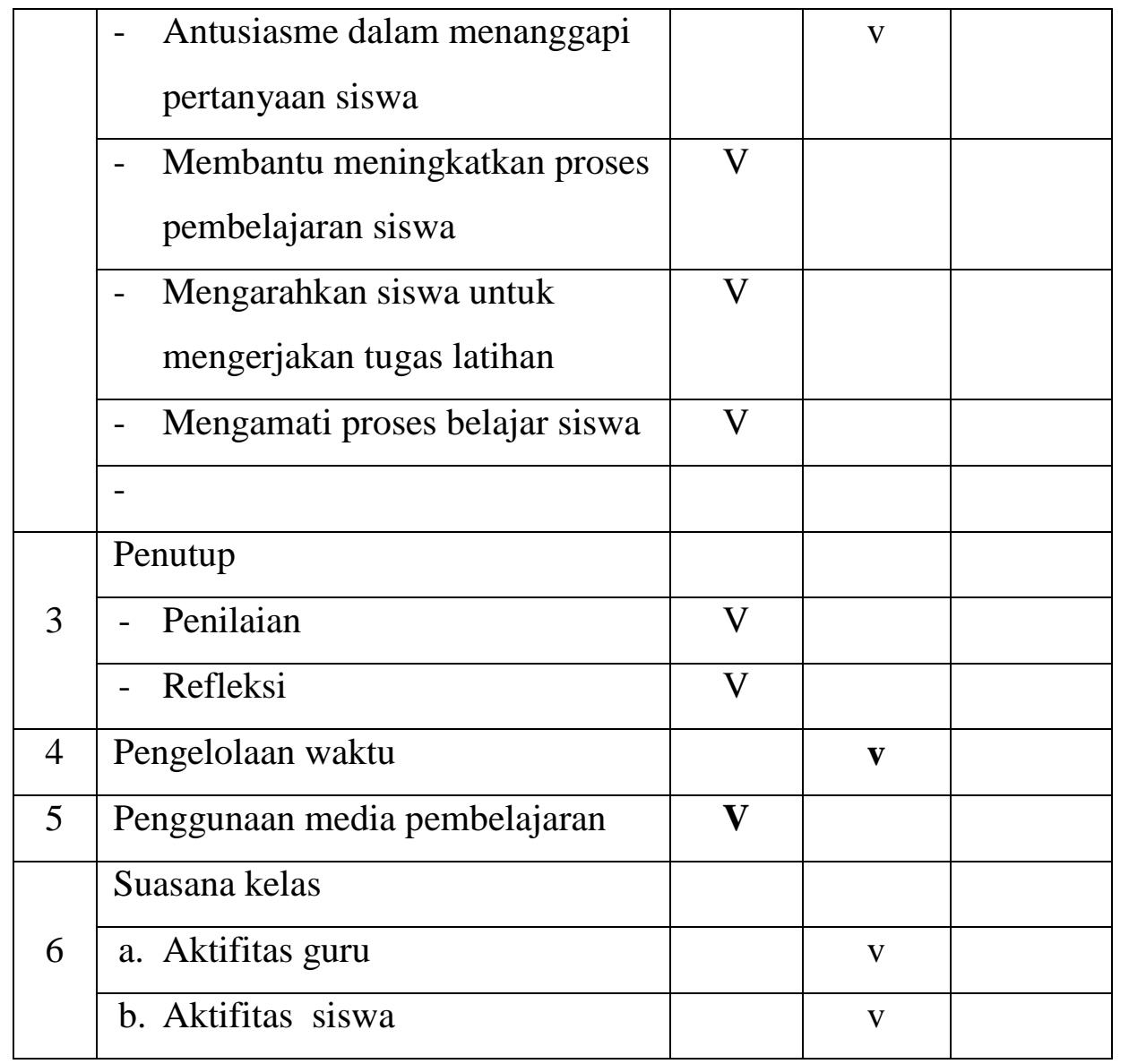

Untuk mengetahui besaran hasil belajar siswa, maka pada akhir siklus I dilakukan penilaian hasil karangan sehingga dapat dilihat pada tabel 4.4 berikut.

Tabel 4.4

Data Hasil Belajar Siswa Pada Siklus I

\begin{tabular}{|r|c|c|l|}
\hline No & Nama Siswa & Siklus I & Ketuntasan \\
\hline 1 & A & 65 & Tuntas \\
\hline 2 & B & 60 & Belum Tuntas \\
\hline 3 & C & 75 & Tuntas \\
\hline 4 & D & 70 & Tuntas \\
\hline 5 & E & 65 & Tuntas \\
\hline 6 & F & 60 & Belum Tuntas \\
\hline 7 & G & 65 & Tuntas \\
\hline
\end{tabular}




\begin{tabular}{|c|c|c|c|}
\hline 8 & $\mathrm{H}$ & 65 & Tuntas \\
\hline 9 & I & 70 & Tuntas \\
\hline 10 & $\mathrm{~J}$ & 75 & Tuntas \\
\hline 11 & $\mathrm{~K}$ & 60 & Belum Tuntas \\
\hline 12 & $\mathrm{~L}$ & 80 & Tuntas \\
\hline 13 & $\mathrm{M}$ & 65 & Tuntas \\
\hline 14 & $\mathrm{~N}$ & 65 & Belum Tuntas \\
\hline 15 & $\mathrm{O}$ & 70 & Tuntas \\
\hline 16 & $\mathrm{P}$ & 60 & Belum Tuntas \\
\hline 17 & $\mathrm{Q}$ & 75 & Tuntas \\
\hline 18 & $\mathrm{R}$ & 65 & Tuntas \\
\hline 19 & $\mathrm{~S}$ & 60 & Belum Tuntas \\
\hline 20 & $\mathrm{~T}$ & 65 & Tuntas \\
\hline 21 & $\mathrm{U}$ & 80 & Tuntas \\
\hline 22 & V & 70 & Tuntas \\
\hline 23 & $\mathrm{~W}$ & 70 & Tuntas \\
\hline 24 & $\mathrm{X}$ & 75 & Tuntas \\
\hline 25 & $\mathrm{Y}$ & 60 & Belum Tuntas \\
\hline 26 & $\mathrm{Z}$ & 75 & Tuntas \\
\hline 27 & A.1 & 60 & Belum Tuntas \\
\hline 28 & A. 2 & 65 & Tuntas \\
\hline 29 & A.3 & 65 & Tuntas \\
\hline 30 & A. 4 & 65 & Tuntas \\
\hline & Rata-Rata & 67,33 & \\
\hline & Nilai Tertinggi & 80 & \\
\hline & Nilai Terendah & 60 & \\
\hline & Persentase Ketuntasan & 76,66 & \\
\hline
\end{tabular}

Berdasarkan tabel 4.4 dan grafik 4.2 terlihat bahwa rata-rata nilai siswa 66,33 dengan nilai tertinggi 80 dan nilai terendah 60. Siswa yang hasil belajarnya diatas 
KKM ada 17 orang atau 56,67\% dari nilai KKM yang ditetapkan yaitu 65. Hal ini memberikan gambaran bahwa ada peningkatan hasil belajar siswa dari prasiklus ke siklus I.

d. Refleksi

Berdasarkan analisis data di atas, masih terdapat kekurangan-kekurangan pada siklus I. Kekurangan-kekurangan tersebut antara lain guru kurang memotivasi siswa, guru terlalu cepat menjelaskan dan alat peraga media gambar yang digunakan kurang menarik perhatian siswa. Dengan adanya kekurangankekurangan tersebut, maka perlu adanya perbaikan-perbaikan dalam KBM untuk siklus II. Perbaikan tersebut yaitu dengan cara memanfaatkan alat peraga media gambar yang menarik sebagai media pembelajaran untuk lebih memotivasi siswa. Selain itu guru harus lebih dapat mengkondisikan siswa, sehingga siswa benarbenar terlibat dalam KBM.

\section{Tindakan Siklus II}

a. Perencanaan Tindakan

1) Sebelum menyusun rencana pembelajaran, peneliti melakukan identifikasi masalah berdasarkan refleksi pada silus I dan merencanakan langkah-langkah yang akan dilaksanakan pada siklus II.

2) Setelah peneliti mengetahui masalah dan langkah-langkah yang akan digunakan pada tindakan di siklus II, peneliti kemudian membuat Rencana Pelaksanaan Pembelajaran (RPP).

3) Menentukan pokok bahasan yang akan dijadikan materi bahasan pada penelitian.

4) Mengembangkan Rencana Pelaksanaan Pembelajaran (RPP).

5) Menyiapkan alat peraga media gambar.

6) Mengembangkan format evaluasi.

7) Mengembangkan format observasi pembelajaran.

e. Pelaksanaan Tindakan

Pelaksanaan tindakan pada siklus II dilaksanakan dalam dua kali pertemuan yaitu sebagai berikut. 
1) Pelaksanaan pembelajaran pada pertemuan pertama

Hari / Tanggal : 23 Agustus 2016

a) Guru terlebih dahulu meneliti tingkat kesiapan siswa, mengecek absensi siswa serta mengondisikan kelas agar pembelajaran dapat berlangsung secara kondusif.

b) Melakukan apersepsi dengan tanya jawab tentang materi yang akan diajarkan.

c). Selanjutnya guru menjelaskan materi secara singkat tentang menganal bagian-bagian utama tumbuhan.

d) Guru menjelaskan materi dengan alat peraga media gambar

e) Siswa mengerjakan latihan soal yang diberikan oleh guru

f) Guru menutup pelajaran dengan membimbing siswa melakukan diskusi secara klasikal untuk menarik kesimpulan dari materi yang telah dipelajari. Dalam kesempatan ini siswa diberi kesempatan untuk menanyakan hal yang belum jelas dari materi yang telah dipelajari.

2) Pelaksanaan pembelajaran pada pertemuan ke dua

Hari / Tanggal : 30 Agustus 2016

a) Guru terlebih dahulu meneliti tingkat kesiapan siswa, mengecek absensi siswa serta mengondisikan kelas agar pembelajaran dapat berlangsung secara kondusif.

b) Melakukan apersepsi dengan tanya jawab tentang materi yang akan diajarkan.

c). Selanjutnya guru menjelaskan materi secara singkat tentang kegunaan bagian- bagian tumbuhan.

d) Guru menjelaskan materi dengan alat peraga media gambar

e) Siswa mengerjakan latihan soal yang diberikan oleh guru

f) Guru menutup pelajaran dengan membimbing siswa melakukan diskusi secara klasikal untuk menarik kesimpulan dari materi yang telah dipelajari. Dalam kesempatan ini siswa diberi kesempatan untuk menanyakan hal yang belum jelas dari materi yang telah dipelajari.

a. Observasi

Pada siklus II ini guru telah melakukan perbaikan-perbaikan. Perbaikan dalam KBM tersebut yaitu guru lebih memotivasi siswa, sehingga siswa lebih 
bersemangat dalam mengikuti KBM. Dengan semangat yang lebih tinggi, maka pembelajaran dapat berjalan lebih baik. Selain memotivasi siswa, guru juga memberikan lebih banyak kesempatan kepada siswa untuk menanyakan hal-hal yang belum jelas dan guru sudah memanfaatkan media pembelajaran dengan baik.

Data mengenai keaktifan siswa dapat diperoleh dengan menggunakan lembar observasi, seperti pada lampiran. Keaktifan siswa tersebut dapat dilihat dalam hal bertanya, mengomentari maupun menyampaikan pendapatnya. Data mengenai keaktifan siswa pada siklus II dapat dilihat pada tabel 4.5

Tabel 4.5

Data Mengenai Keaktifan Siswa Pada Siklus II

\begin{tabular}{|c|c|c|c|c|}
\hline \multirow{2}{*}{ No } & \multirow{2}{*}{ Nama } & \multicolumn{3}{|c|}{ Perhatian Siswa } \\
\hline & & B & C & K \\
\hline \hline 1 & A & $\sqrt{ }$ & & \\
\hline 2 & B & $\sqrt{ }$ & & \\
\hline 3 & C & $\sqrt{ }$ & & \\
\hline 4 & D & $\sqrt{ }$ & & \\
\hline 5 & E & $\sqrt{ }$ & & \\
\hline 6 & F & $\sqrt{ }$ & & \\
\hline 7 & G & $\sqrt{ }$ & & \\
\hline 8 & H & $\sqrt{ }$ & & \\
\hline 9 & I & $\sqrt{ }$ & & \\
\hline 10 & J & $\sqrt{ }$ & & \\
\hline 11 & K & $\sqrt{ }$ & & \\
\hline 12 & L & $\sqrt{ }$ & & \\
\hline 13 & M & $\sqrt{ }$ & & \\
\hline 14 & N & $\sqrt{ }$ & & \\
\hline 15 & O & & $\sqrt{ }$ & \\
\hline 16 & P & $\sqrt{ }$ & \\
\hline 17 & Q & & & \\
\hline
\end{tabular}




\begin{tabular}{||c|c|c|c|c|}
\hline 18 & $\mathrm{R}$ & $\sqrt{ }$ & & \\
\hline 19 & $\mathrm{~S}$ & $\sqrt{ }$ & & \\
\hline 20 & $\mathrm{~T}$ & $\sqrt{ }$ & $\sqrt{ }$ & \\
\hline 21 & $\mathrm{U}$ & $\sqrt{ }$ & & \\
\hline 22 & $\mathrm{~V}$ & $\sqrt{ }$ & & \\
\hline 23 & $\mathrm{~W}$ & $\sqrt{ }$ & & \\
\hline 24 & $\mathrm{X}$ & $\sqrt{ }$ & & \\
\hline 25 & $\mathrm{Y}$ & $\sqrt{ }$ & & \\
\hline 26 & $\mathrm{Z}$ & $\sqrt{ }$ & & \\
\hline 27 & A.1 & $\sqrt{ }$ & & \\
\hline 28 & A.2 & $\sqrt{ }$ & & \\
\hline 29 & A.3 & $\sqrt{ }$ & & \\
\hline 30 & A.4 & & & \\
\hline
\end{tabular}

Di bawah ini hasil pengamatan observer tentang aktivitas guru pada siklus II dapat dilihat pada tabel 4.6.

Tabel 4.6

Data Hasil Pengamatan Aktivitas Guru Pada Siklus II

\begin{tabular}{|c|c|c|c|c|}
\hline \multirow[t]{2}{*}{ No } & \multirow[t]{2}{*}{ Aspek Yang Diamati } & \multicolumn{3}{|c|}{ Penilaian } \\
\hline & & Baik & Cukup & Kurang \\
\hline \multirow{3}{*}{1} & Pendahuluan & & & \\
\hline & c. Memotivasi siswa & $\sqrt{ }$ & & \\
\hline & d. Apersepsi & $\sqrt{ }$ & & \\
\hline \multirow{4}{*}{2} & Kegiatan Inti & & & \\
\hline & $\begin{array}{l}\text { - Bahan bahan pembelajaran yang } \\
\text { disajikan sesuai dengan yang } \\
\text { direncanakan }\end{array}$ & $\sqrt{ }$ & & \\
\hline & $\begin{array}{l}\text { - Kesesuaian alat peraga dengan } \\
\text { materi }\end{array}$ & $\sqrt{ }$ & & \\
\hline & - Kemampuan mengoptimalkan & $\sqrt{ }$ & & \\
\hline
\end{tabular}




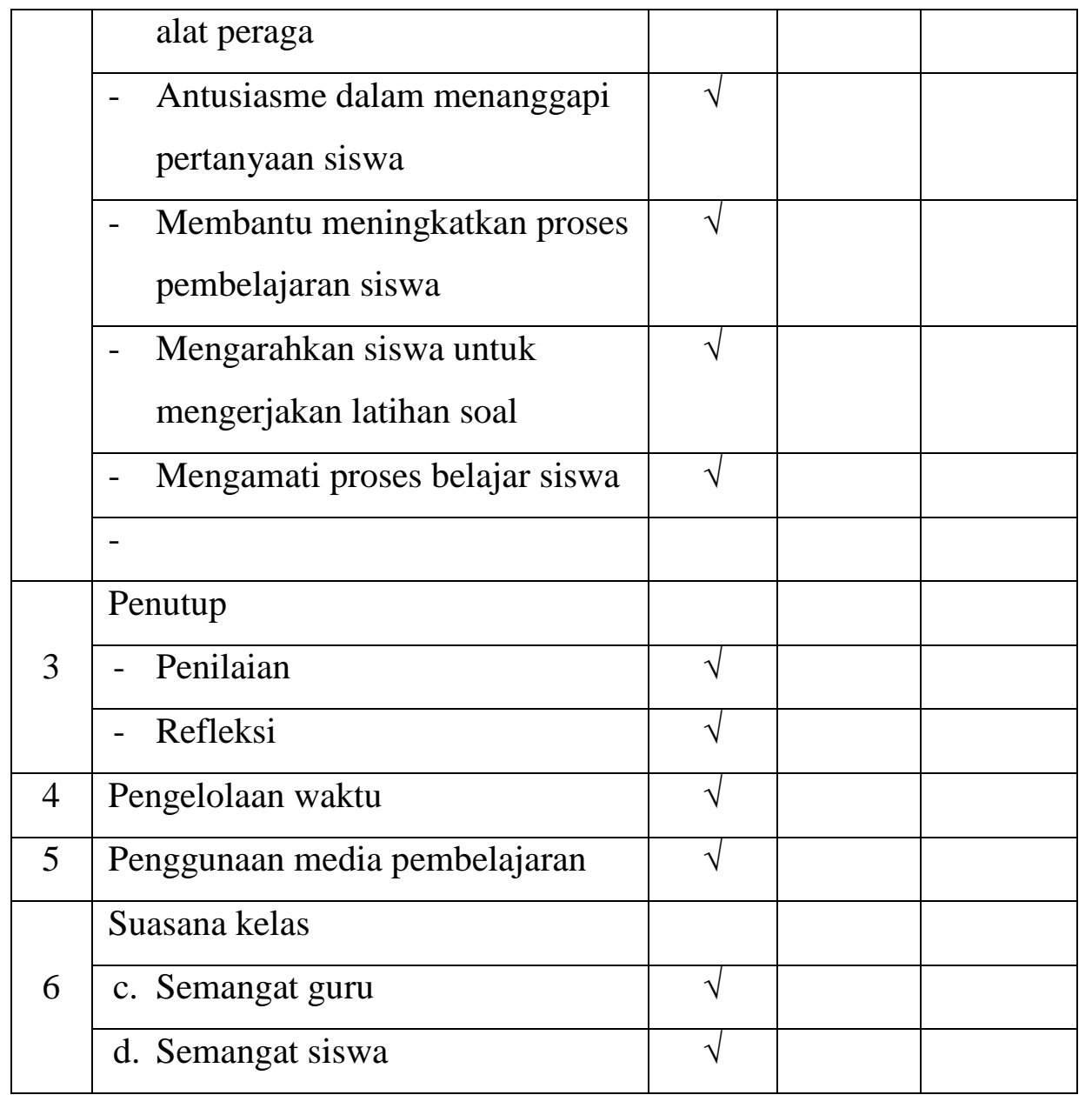

Untuk mengetahui besaran hasil belajar siswa, maka pada akhir siklus II dilakukan tes dengan hasil belajar dapat dilihat pada tabel 4.7 berikut.

Tabel 4.7

Data Hasil Belajar Siswa Pada Siklus II

\begin{tabular}{|r|c|c|c|}
\hline No & Nama Siswa & $\begin{array}{c}\text { Siklus } \\
\text { II }\end{array}$ & Ketuntasan \\
\hline 1 & A & 80 & Tuntas \\
\hline 2 & B & 80 & Tuntas \\
\hline 3 & C & 80 & Tuntas \\
\hline 4 & D & 75 & Tuntas \\
\hline
\end{tabular}




\begin{tabular}{|c|c|c|c|}
\hline 5 & $\mathrm{E}$ & 80 & Tuntas \\
\hline 6 & $\mathrm{~F}$ & 70 & Tuntas \\
\hline 7 & $\mathrm{G}$ & 75 & Tuntas \\
\hline 8 & $\mathrm{H}$ & 70 & Tuntas \\
\hline 9 & I & 90 & Tuntas \\
\hline 10 & $\mathrm{~J}$ & 80 & Tuntas \\
\hline 11 & K & 70 & Tuntas \\
\hline 12 & $\mathrm{~L}$ & 95 & Tuntas \\
\hline 13 & $\mathrm{M}$ & 80 & Tuntas \\
\hline 14 & $\mathrm{~N}$ & 70 & Tuntas \\
\hline 15 & $\mathrm{O}$ & 70 & Tuntas \\
\hline 16 & $\mathrm{P}$ & 70 & Tuntas \\
\hline 17 & Q & 85 & Tuntas \\
\hline 18 & $\mathrm{R}$ & 70 & Tuntas \\
\hline 19 & $S$ & 70 & Tuntas \\
\hline 20 & $\mathrm{~T}$ & 70 & Tuntas \\
\hline 21 & $\mathrm{U}$ & 90 & Tuntas \\
\hline 22 & V & 80 & Tuntas \\
\hline 23 & W & 90 & Tuntas \\
\hline 24 & $\mathrm{X}$ & 85 & Tuntas \\
\hline 25 & $\mathrm{Y}$ & 70 & Tuntas \\
\hline 26 & $\mathrm{Z}$ & 80 & Tuntas \\
\hline 27 & A. 1 & 70 & Tuntas \\
\hline 28 & A. 2 & 75 & Tuntas \\
\hline 29 & A.3 & 80 & Tuntas \\
\hline 30 & A. 4 & 75 & Tuntas \\
\hline & Rata-Rata & 77,50 & \\
\hline & Nilai Tertinggi & 95 & \\
\hline & Nilai Terendah & 70 & \\
\hline & Persentase Ketuntasan & 100,00 & \\
\hline
\end{tabular}


Berdasarkan tabel terlihat bahwa rata-rata nilai siswa 77,50 dengan nilai tertinggi 95 dan nilai terendah 70. Siswa yang hasil belajarnya diatas KKM ada 30 orang atau $1007 \%$ dari nilai KKM yang ditetapkan yaitu 65. Hal ini memberikan gambaran bahwa ada peningkatan hasil belajar siswa dari siklus I ke siklus II.

b. Refleksi

Dari data di atas didapat bahwa hampir seluruh siswa menyukai pembelajaran dengan menggunakan alat peraga media gambar. Hal ini dikarenakan siswa merasa tertarik dan termotivasi dalam KBM yang menggunakan alat peraga media gambar.

\section{B. Pembahasan}

Dari hasil pembelajaran menggunakan alat peraga media gambar dan jawaban soal-soal evaluasi yang diberikan, kemudian penulis menggunakan jawaban-jawaban tersebut untuk mengetahui apakah pembelajaran mengarang menggunakan alat peraga media gambar tesebut dapat meningkatkan hasil belajar siswa kelas II MI No. 43/E.3 Tamiai Kabupaten Kerinci.

Berdasarkan hasil penelitian selama dua siklus yang bertujuan untuk meningkatkan hasil belajar siswa pada materi mengenal bagian-bagian utama hewan dan tumbuhan, terlihat pada pelaksanaan siklus pertama dan ke dua telah menunjukkan hal-hal sebagai berikut :

1. Proses pembelajaran menulis karangan dengan menggunakan alat peraga media gambar ditinjau dari segi interaksi siswa dan guru :

a. Pada awal pelajaran, guru membuka dengan menggunakan alat peraga media gambar sebagai titik tolak pelajaran. Kemudian guru mengarahkan dan menjelaskan bagaimana siswa belajar dengan baik.

b. Pada saat proses pembelajaran berlangsung, guru mengelola kelas secara interaktif, membimbing siswa, dan memotivasi siwa untuk aktif berperan dalam kegiatan pembelajaran. 
c. Pada akhir pelajaran, guru bersama siswa menyimpulkan pelajaran yang telah dilaksanakan. Kemudian guru mengevaluasi siswa dengan memberikan soal-soal relevan terhadap konsep pada kesimpulan.

2. Ditinjau dari keefektifan alat peraga

Jika kita melihat data di atas, akan tampak keefektifan penggunaan alat peraga media gambar pada siklus ke dua yang terbukti adanya peningkatan nilai rata-rata yaitu 77,50 walaupun masih ada siswa yang memperoleh nilai di bawah rata-rata. Hal itu sudah menandakan bahwa penggunaan alat peraga pada pembelajaran siklus ke dua memberikan kontribusi yang cukup besar bagi peningkatan hasil belajar belajar siswa.

\section{E. KESIMPULAN DAN SARAN}

\section{Kesimpulan}

Berdasarkan hasil yang telah dilaksanakan dalam dua siklus dan indikatorindikator yang telah ditetapkan, maka dapat dikemukakan simpulan sebagai berikut :

1. Minat dan kemampuan siswa terhadap pembelajaran menulis karangan sangat baik.

2. Media Gambar sangat membantu siswa dalam meningkatkan imajinasi sehingga mampu membuat kalimat sederhana yang menjadi kerangka karangan dan kemudian dikembangkan lagi.

3. Siswa mampu menginterprestasikan kalimat sederhana dengan cara mengkaitkan gambar seri yang diamatinya.

4. Siswa mampu mengkomunikasikan tulisannya berdasarkan hasil pengamatan kepada temannya maupun kepada guru.

5. Proses pembelajaran lebih variatif sehingga anak menjadi kreatif, aktif dan menyenangkan.

6. Pembelajaran lebih efektif, karena terfokus pada media gambar.

7. Pembelajaran akan kondusif, karena perhatian siswa tertuju pada media gambar yang telah disediakan. 
8. Guru mudah untuk mengevaluasi hasil kegiatan anak terutama pada aspek minat dan kemampuan siswa.

9. Dapat dijadikan tolak ukur pada pembelajaran berikutnya.

\section{Saran}

1. Guru-guru Sekolah Dasar harus terus menggiatkan pelaksanaan penelitian tindakan semacam ini, sehingga nantinya akan diperoleh berbagai strategi dalam upaya peningkatan kualitas pembelajaran, yang pada akhirnya akan dapat meningkatkan kualitas dan kredibilitas suatu sekolah.

2. Agar guru selalu meningkatkan profesionalismenya guna meningkatkan kualitas pendidikan. Untuk itu guru harus selalu mengadakan perubahan-perubahan didalam melaksanakan pembelajaran. Guru perlu melakukan Penelitian Tindakan Kelas untuk merekam semua kegiatan pembelajarannya sehingga dapat diketahui kelebihan dan kekurangannya untuk perbaikan pembelajaran berikutnya.

3. Adanya tindak lanjut pada penelitian tindakan kelas ini agar siswa mampu memahami dan menerapkan pemahaman tentang pelajaran yang dipelajarinya

4. Pihak sekolah harus mulai terbuka dalam menerima inovasi atau perubahan positif dan pengembangan baik sistem pengajaran, sarana prasarana yang dapat meningkatkan kualitas pembelajaran, sehingga hasil pembelajaran dapat berkembang secara optimal. 